\title{
Toward English as an International Language Perspective: Reconception of 'Proficiency in English' for the Indonesian Local Context in Today's World
}

\author{
Sri Imelwaty, Trisna Helda, Edwar Kemal, Zaitun, Zainudin Hassan
}

\begin{abstract}
For many years, English Language Teaching (henceforth ELT) in Indonesia has adopted a monolithic view toward the so-called 'native speaker English' as an ideal target language. However, this view has been challenged by the pluralistic view of English. Sociolinguistics realities indicate the plurality of the English language has grown enormously around the world. In term of English proficiency, this notion is made more complicated in the absence of any unitary framework and by the diverse meanings arising from in its use as a global language. The aim of this study is to identify the attributes of 'Proficiency in English' which suits with the local needs for the Indonesian context in today's world. To this end, the personal constructs of a small number of English teachers were explored and identified. A Repertory Grid interview technique was used to elicit the meanings of 'Proficiency in English' which were based on the teachers' understanding. For analyzing the qualitative data, a thematic analysis was employed to formulate the themes. These teachers of English revealed that they perceived 'Proficiency in English' comprising knowledge of English and abilities to apply it in real situations. Surprisingly, they also declared that to be proficient in English, one should have intercultural competence and employ it for the intercultural and cross-cultural communications internationally which has been advocated by the English as an International language (henceforth EIL) perspective. The findings of this study could be used to inform ELT program and its practices in the Indonesian context.
\end{abstract}

Index Terms: EIT, ELT, Proficiency, Pluralistic View, Exonormative, Endonormative.

\section{INTRODUCTION}

The global spread of English and the current Sociolinguistic realities have led to the emergence of the various frameworks 'to conceptualize, research and teach English' [1]. These frameworks i.e. World Englishes (WE), English as Lingua Franca ELF) and English as an International Language (EIL), have shifted applied linguists' paradigm from the traditional monolithic view of English into pluralistic one. Although these frameworks focus on different foci, they all belong to the 'anti-normative paradigms' [2] which challenge the notion of the supremacy of the native

Revised Manuscript Received on April 19, 2019.

Sri Imelwaty, STKIP PGRI Padang, Sumatera Barat, Indonesia. *(Email: imelwaty05@stkip-pgri-sumbar.ac.id)

TrisnaHelda, STKIP PGRI Padang, Sumatera Barat, Indonesia.

Edwar Kemal, STKIP PGRI Padang, Sumatera Barat, Indonesia.

Zaitun, Universitas Muhammadiyah Jakarta, Indonesia

Zainudin Hassan, Department of Educational Foundation and Social

Sciences, Universiti Teknologi Malaysia, Johor, Malaysia. speakers' English norms such as 'the Queen's English', 'Received Pronunciation', or 'General American'.

While the three perspectives i.e. WE, EFL, EIL on occasion have been used interchangeably, they are completely having different features. According to McKay [3], WE concerns on the content which defines the distinctive features of various varieties of English not interaction; ELF concerns on the content which focuses on the interaction between non-native speakers of English and with interaction. Then, EIL is "concerned with both content and interaction, its main focus is on particular principles" [3]. This means that EIL embraces the ideas of varieties of English and acknowledges that many contextual factors influence the users of English language in term of what to use and how to use English.

This paradigm shift from a monolithic view to a pluralistic view in ELT is the result of the status of English in the global world as an international language [4],[5]. English holds an important role in world economy and in a range of cultural activities, for examples film industries, pop music, tourism, publications and education [6],[7],[8],[9],[10]. Besides that, there are more than 70 countries in the world have given special status of English as an official language [11]. This leads to the current conditions of the English users that they are bilingual or even multilingual users of English and they use English in plurilingual contexts [8],[9],[12],[13]. In addition, Graddol [14] adds that there are more than $80 \%$ of English communications exist between bi-/multilingual speakers of English.

The changing of the demographic and geographical conditions of English in the world today also influences the structural condition of the English itself. Various varieties of English have emerged due to the increasing number of bi-/multilingual speakers of English [15],[16]. Numerous studies which were published in academic journals such as World Englishes, English Today, and English World Wide, have shown the different varieties of English which is being 'appropriated' [17] and 're-nationalised' [6] to 'suit the local tastebud' [18]. Thus, it is an avoidable condition that English belongs to anyone who use it and it has been pluralized by its users to show their cultural identities and their cultural conceptualisation when they communicate their ideas [19]. 
With respect to the notion of English proficiency, it has engaged the interest of teachers, administrators, curriculum developers, test constructors, researchers, parents and students for several decades now. The framing of 'proficiency' as a language learning outcome is required not only by English language educators, but also by English language learners. It is the notion that is commonly assumed as the aim for language teaching and learning [20]. The traditional view in ELT has regarded the 'Standard' British or American English as it is used by the native speakers of English becomes the ultimate goals for teaching and learning English in the context where English does not have an official status but have an important role. However, this view is no longer applicable as sociolinguistic realities have shown multiple varieties of English which are used by multicultural communities in the world. Therefore, the entities attached to the notion of 'Proficiency in English' should be reconceptualised which accommodate the needs of the local context in today's world.

In the Indonesian context, to be proficient in English is considered necessary in many aspects of life and particularly for people in the larger cities. For example, in order to secure good employment such as an office manager or administrator, many institutions and companies prefer applicants who are proficient in English. The high value that is placed on English language proficiency can be seen in many job advertisements in the national newspapers that state proficiency in English as a requirement [21]. It has become a common assumption that 'Proficiency in English' has become a gate-keeper to ensuring the quality of Indonesian human resources.

As a result, English is widely used in Indonesia and is seen as an important tool in the development of the country. The demand for proficient English speakers continues to increase. However, teachers of English and English language learners still prefer the 'exonormative' models (the models of English which rely on foreign forms and customs or it is originated from the outside the place where it is spoken, commonly assumed as British or American English in the Indonesian context) to the 'endonormative' ones (the models of English which refer to the locally grown varieties of English). It is argued that if teachers of English in the Indonesian context are still holding on the traditional view in using standard American or British English as a reference in ELT, this could be a hindrance for the language educators to prepare English language learners to compete and to build good rapports among the global communities in the world.

A seminal scholar in EIL, Canagarajah [22] has called for a need to define the meaning of 'Proficiency in English' as having 'the ability to shuttle between different varieties of English and different speech communities'. In a similar vein, Mahboob and Dutcher [23] also argue that 'being proficient in a language implies that we are sensitive to the setting of the communicative event, and have the ability to select, adapt, negotiate, and use a range of linguistic resources that are appropriate in the context.' This means that 'Proficiency in English' for today's world comprises the awareness of varieties of English and the ability to use English in a range of various contexts.

As the monolithic view of English has still remained amongst English language educators in Indonesia and the pluralistic view of English has already grown in ELT, it is necessary to reconceptualise the notion of 'Proficiency in English' for the Indonesian local context. There remains no consensus on what 'proficiency in English' means amongst teachers of English in Indonesia and the prevalence of a range of English varieties has generated considerable complexity in establishing any consistent understanding of 'proficiency in English' in the Indonesian ELT context for the English learners' successful communication in today's globalized world. The need to reformulate a stable definition of 'Proficiency in English' is necessary for Indonesian teachers of English.

In addition; there is a dearth of literature discussing the topic under study, particularly in the Indonesian context. Previous studies have already shown the representations of the 'native speakerism' as the typical realities in ELT where English is regarded as foreign language. The native- speaker Englishes (e.g. British or American English) often become the preferred varieties to be taught and learned [24],[25] and the ideal target is the native speakers proficiency [26]. The native English teachers are considered better particularly on their linguistic advantage comparing to the non-native teachers [27]. Furthermore, the Anglophone cultures are dominantly introduced and taught than any other cultures from other parts of the world [28],[29]. The conditions as depicted in those studies are also available in the Indonesian context particularly in adopting exonormative models of English i.e. American or British English in their teaching practices [30].

The aim of this study is to identify the attributes which are attached to the notion of 'Proficiency in English' by exploring the English language educators' personal constructs. The teachers of English were encouraged to reveal the attributes of 'proficiency in English' as understood and interpreted by them within the current conditions of today English in the world. Thus, their understanding of what it meant to be proficient in English, particularly for the Indonesian context would be described in this article addressing the research question: What are the teachers of English perceptions of the notion of 'Proficiency in English' in today's world?. The findings of this study may provide insights for English language educators, curriculum developers and educational institutions policy makers in Indonesia or in other non-English speaking countries to reconceptualize the notion of 'Proficiency in English'.

\section{METHOD}

The study was qualitative in nature which employed a case study design. According to Yin [31], the feature of case study is "the distinctive need for case studies arises out of desire to understand complex social phenomena" as "the case study method allows investigators to retain the holistic and meaningful characteristics of real-life events". As this study tried to identify the attributes of the notion of 'Proficiency in English' based on the teachers of English understanding, this research design was considered applicable.

The qualitative data were collected using a developed interview instrument for eliciting teacher-trainers' personal constructs. The instrument for collecting qualitative data adopted the principles of Repertory Grid technique. While originally developed within the field of clinical psychology, 
Repertory Grid technique [32] has long been recognized as a flexible method for eliciting personal constructs [33],[34] and has been included in different methodologies for a diverse range of research purposes.

Personal constructs are used to shape perceptions so that it is assumed that people cannot conceptualize an object which is not covered by a construct. According to George Kelly [32] who developed the theory of personal constructs, everyone has his/her own personal ideas, philosophies, and theories about the world [35]. Therefore, by using personal constructs, individuals make their own interpretations of their experiences, share their views and appreciate others' interpretations [35]. Fransella and Banister [33], after Kelly [32] suggest a personal construct is generated when an individual describes 'a way in which two or more things alike and thereby different from a third or more things' (p.5). Even though not the most comprehensive way of describing personal constructs, for the purpose of this study, this was deemed adequate. Kelly further argued that constructs are bipolar in nature because individuals never affirm anything without simultaneously denying something else [33]. More simply, a construct is an abstract idea created by individuals through examination of similarities and differences as Coshall [36] describes that constructs as individuals' personal interpretations and assessments of the environment around them. In this study, English teachers' descriptions of the qualities regarding 'proficiency in English' became the constructs under study.

Purposive sampling [37] was employed for recruiting the participants of this study. All participants had higher education degrees in teaching English. They were therefore assumed to have knowledge of the subject matter, the English language, and the pedagogical content required for teaching English in the Indonesian context. The process of data collection was stopped as the data reached saturation. In total, there was a small group of twelve English teachers were interviewed with a range of experiences in ELT from 3 to more than 10 years. They were asked to choose which of the two out of the three provided statements regarding the descriptions of 'Proficiency in English' that they think have most in common and why the third description is different from those two descriptions. Following up to their previous responses, they were further asked to clarify their responses. For this purpose, participants were asked why they had preferred one construct over another. All interviews were tape recorded and transcribed verbatim.

For analyzing the qualitative data, a thematic analysis was employed. Braun and Clarke [38] explain that thematic analysis is used for 'identifying, analyzing, and reporting patterns (themes) within the data'. The results of the analysis were the formulation of the themes which capture the key ideas about the data in relation to the research question and which represent some level of patterned response or meaning within the data set [38]. In other word, a theme would describe the expression of the latent content [39] as it might be in the abstract forms.

\section{RESULTS}

The attributes of 'Proficiency in English' for the
Indonesian local context, which were construed by the teachers of English, fell into two themes. They are: 1) exonormative constructs i.e. the ideas which comprise the 'native-speakerism' [40] denoting Standard British or American English as a reference; and 2) endonormative constructs i.e. the ideas which include the localized forms of English and the orientation of different varieties of English Within each of the two themes, the teachers perceived 'Proficiency in English' as having not only the knowledge of language but also the abilities to use the knowledge in real life situations. The attributes of 'Proficiency in English' which were reflected in their personal constructs are described as follow:

\section{a. Exonormative constructs}

The teachers construed that for being proficient in English, someone needs to have the knowledge of English language particularly both the knowledge of know-what and know-how of which were understood by them as prescribed rules of English language. This is depicted in the following statement:

To be proficient in English, we do not only master the structure of English language but also have to know how the English speakers use their language (Participant E)

The following quote shows evidence of the strong orientation to write correctly using the rules of American or British English:

In writing, accurate norms or rules of language should be followed (Participant A)

In the academic context, 'Proficiency in English' was drawn strongly on prescribed academic English involving the exonormative models of English in particular:

'Proficiency in English', I would like to focus its meaning on English proficiency tests for academic purposes (Participant $C$ )

When our ability is being tested in academic context, we are strictly relating to prescribed norms (Participant B)

Furthermore, the English of the 'native speakers' from educated classes appeared continually in the teachers' constructs:

English of the educated native speakers is regarded as 'Standard English' language (Participant G)

It is a common assumption amongst English language educators in Indonesia that only scholars or highly educated people have the ability to use the prescribed forms in academic contexts. Moreover, by achieving this standard, one is marked as an educated person. With regard to spoken language, a preference for the exonormative models of spoken British or American English was also evident:

Modeling our English on one accent either American accent or British accent (Participant K)

b. Endonormative constructs

The attributes of 'Proficiency in English' were also construed by the teachers as having the knowledge of the various communities and the contexts in which English is being used. Therefore, a proficient speaker of English was perceived to have knowledge and an understanding of the varieties of English to successfully communicate with the native English and non-native English speakers from a 
different range of communities. The proficient speaker was perceived for having the abilities to adapt their language depending on when and how the situation deems it is used. This teacher however implies that endonormative models of English are 'ungrammatical':

It depends on the contexts when we have to use grammatical language and when not to use it, it is based on the context, and it is flexible... in speaking, it is flexible. It is not necessary to be grammatical as long as others understand it, but in academics, it is necessary (Participant A)

With respect to the abilities, the teachers also perceived that 'Proficiency in English' comprises the ideas of the intercultural communication by stating the ability to communicate with both native and non-native speakers of English:

It is an ability to communicate interpersonally with others who are native speakers and non-native speakers...(Participant H)

We need to use English with people in non-English speaking countries who use English as a second language (Participant E)

The idea which included the use of local norms was then stated, thus broadening the scope to include intercultural communication:

It is an ability to use English based on the local norms of those non-native speakers...(Participant B)

Being proficient in English was perceived for having the knowledge of recognition of cultural and linguistic influences that serve to create local variants of English:

Using English without eliminating local norms of the countries in which English is used and learnt (Participant D)

The ability for being intelligible, specifically in oral communication was suggested as the underlying aim of speech to make meaning:

If it is only for communication, maybe we do not need to know specific things [prescribed syntactic rules or the syntax of grammatical utterances in speaking] (Participant E)

In speaking, it seems that it does not follow accurate grammar [the prescribed rules of how to arrange words into sentences] but actually it isn't like that.....so the ability of using English language is how we express our ideas meaningfully (Participant A).

\section{DISCUSSION}

For the purpose of this study, EIL perspective was adopted as a perspective [12] or "a paradigm for thinking, research, and practice" [5] to understand the teachers of English reconceptualization of 'Proficiency in English'. In addition, Marlina [18] argues that this perspective is a kind of "linguistic and epistemological lens for researchers, scholars, and educators to put on in order to critically: revisit and reconsider their ways of conceptualising English; re-assess their analytical tools and approaches they adopt in the sociolinguistics of English and TESOL disciplines; and revise their pedagogical strategies for English language education in the light of the tremendous changes that English has undergone as a result of its global expansion in recent decades" [11]. In other words, this perspective could inform the researchers' understanding of the phenomena of today's English for ELT context.

Findings of this study show that 'Proficiency in English' for the Indonesian context was construed by the teachers of English into two different constructs. There are evidences in this study that the teachers were ambivalent toward the attributes of this notion. However, they seemed having a consensus on what one should have for being proficient in English i.e. knowledge of language and abilities to use the knowledge of language in real life situations. This is understood as their practices as teachers of English involve with the linguistic knowledge and made their students have abilities to apply the knowledge.

Having conscious knowledge of grammar rules concerning the sentence structure or explicit metalinguistic awareness was regarded as important knowledge for academic context particularly for written language. The teachers considered that 'Standard' American or British English is appropriate for academic purposes and local varieties of English are not the 'Standard English' in academic context. This might be the result of the dominant norms in ELT in Indonesia for many years. In term of abilities, the exonormative models of English are still being fancy by the teachers for spoken language. On a practical level, prescribed English rules were generally deemed as only relevant for writing purposes and particularly in academic contexts. Thus, the attributes of 'Proficiency in English' which were covered in the exonormative constructs reflect the typical conditions in ELT not only in Indonesia but also in other non-English speaking countries [24],[25],[26],[30].

Eventhough the teachers indicated an orientation toward a monolithic view of English which evokes exonormative models of English particularly within academic contexts, they had also indicated knowledge to understand and use English for communication purposes which would encompass endonormative models of English. In the endonormative construct of 'proficiency in English', it revealed their conceptual understanding of the practical abilities or skills needed for using English language in today's world. These skills were more focused on the communicative purposes, but were limited to informal situations and for intercultural communications. In this respect, contextual awareness of the varieties of English was considered important when exercising communicative skills. This kind of attribute of 'Proficiency in English' accords with EIL perspective which encourages English language teachers, users and learners to 'revisit and reconsider their ways of conceptualizing English' [11].

In the context of speaking, there was a collective tendency to support the communication of meaning rather than of 'correct' form. For example, intelligibility was preferred to imitating the so-called 'native speakers' of English. These findings may be suggestive of those teachers' concerns of their English which could not achieve imitating the exonormative models of English. Therefore, it is understandable that they tolerated the use of endonormative models of English within spoken discourse as long as the meaning is communicated. This also indicated the teachers' awareness of the local English norms in spoken discourse, particularly in local contexts. The ideas toward awareness of different varieties and contexts for being proficient in English 
have been advocated by Canagarjah [22], Mahboob and Dutcher [23].

Based on the findings of this study, it is argued that the notion of 'Proficiency in English' for the local context in Indonesia have already been reconceptualised by the Indonesian teachers of English toward EIL perspective. The attributes of this notion encompass English for global communication in today's world. Both exonormative and endonormative models of English have been included within the attributes. This means further enhancements toward EIL perspective and exposures to various varieties of English are needed for English language educators, users, and learners in Indonesian local context in order to strengthen their understanding of the frame work of 'Proficiency in English' for today's world.

\section{CONCLUSION}

The attributes of 'Proficiency in English' as understood by the teachers of English were identified into two recurrent themes i.e. exonormative and endonormative constructs which both reflecting the knowledge of language and the abilities to use the knowledge in real life situations.The teachers perceived a range of attributes which were embodied in 'proficiency in English' embracing the plurality of English as being advocated by EIL perspective. Being proficient in English in today's world is not only referring to one variety of English but also to the awareness of various varieties of English. Although the teachers still perceived 'Proficiency in English'as achieving the 'native speakers' proficiency; they have already seen its limitation for using it in academic contexts. While for everyday purposes, the acknowledgment of varieties of English is viable. This study has displayed the reconception of the notion of 'Proficiency in English' toward EIL perspective which suggests the state of being proficient in English encompassing the awareness of intercultural and cross-cultural communication. Focusing on a single variety of English is not enough as communication in English happens in various contexts. Thus, being able to shuttle and to adjust within different varieties of English is needed by English language learners and users in today's world. As this study limited its exploration to a small number of English teachers in Indonesia, further work should be undertaken to validate the feasibility of the reconception of 'Proficiency in English' within EIL perspective for the Indonesian local context in today's world, to a large cohort of teachers of English.

\section{ACKNOWLEDGMENT}

This study was a part of the research project which was funded by in the Ministry of Research, Technology and Higher Education of Republic of Indonesia in 2018. We also thank to the teachers of English in West Sumatra, Indonesia who have participated in the research process and provided insights that greatly assisted our research project.

\section{REFERENCES}

1.S. Dogancay-Aktuna, J. Hardman,. Teaching of English as an International Language in Various Contexts: "Nothing Is as Practical as Good Theory". RELC Journal: A Journal of Language Teaching and Research, 2018, 49(1), pp.74-87.

2.R. Kubota,. The politics of EIL: Toward border-crossing communication in and beyond English. In A. Matsuda (Ed.), Principles and practices of teaching English as an international language. Bristol: MultilingualMatters. 2012, pp.55-69.

3. S. L. McKay,. English as an International Language: What it is and what it means for pedagogy. RELC Journal: A Journal of Language Teaching and Research, 20108, 49 (1), pp.9-23.

4. M. Saraceni,. Relocating English: Towards a new paradigm for English in the world. Language and Intercultural Communication, 2009, 9(3), pp.175-186.

5. F. Sharifian,. English as an international language: Perspectives and pedagogical issues. Bristol: MultilingualMatters. 2009.

6. S. L. McKay. Teaching English as an international language. Oxford: Oxford University Press. 2002.

7.S. L. McKay. English as an international language.In N.Hornberger\&S. L.McKay (Eds.), Sociolinguistics and language education. Bristol: MultilingualMatters. 2010, pp.89-115.

8. S. L. McKay. Principles of teaching English as an international language. In L. Alsagoff, S. L. McKay, G. Hu, \& W. A. Renandya (Eds.), Principles and practices for teaching English as an international language. New York: Routledge. 2012, pp.28-46.

9.D. Crystal. English as a global language. Cambridge: Cambridge University Press. 1997.

10. D. Graddol. The future of English. London: British Council 1997.

11. R. Marlina. The Pedagogy of English as an International Language ( EIL ): More Reflections. In The Pedagogy of English as an International Language: Perspectives from Scholars, Teachers, and Students 2014, pp.1-20 https://doi.org/10.1007/978-3-319-06127-6

12. S. L. McKay \& W. Bokhorst-Heng. International English in its sociolinguistic contexts: Towards a socially sensitive EIL pedagogy. London: Routledge. 2008.

13. D. Graddol. The decline of the native speaker. AILA Review, 1999, 13, pp.57-68.

14. D. Graddol. English next. London: British Council. 2006

15. D. Graddol. English in the future. In A. Burns \& C. Coffin (Eds.), Analysing English in a global context. New York: Routledge. 2001, pp.26-37

16. B. B. Kachrul. The alchemy of English. 1986. Oxford: Pergamon Press.

17. S. Canagarajah, S. Resisting linguistic imperialism in English teaching. 1999. Oxford: Oxford University Press.

18. R. Marlina. Teachers of Englishes. English Teaching Professional, 2010, 66, pp.47-49, Keyways Publishing: Chichester.

19. F. Sharifian. Cultural conceptualisations and language. Amsterdam: John Benjamins \&Co. 2011.

20. C. Harsch. Key concepts in ELT Proficiency.ELT Journal 2017, 7, pp.1-2.

21. M. Lamb \& H. Coleman. Literacy in English and transformation of self and society in post-Suharto Indonesia.The International Journal of Bilingual Education and Bilingualism, 2008, 11(2), pp.189-205.

22. S. Canagarajah. Redefining proficiency in global English. In: Zacharias N, Manara C (eds) Contextualizing the Pedagogy of English as an International Language: Issues and Tensions. Newcastle upon Tyne: Cambridge Scholars Publishing, 2013, pp. $2-11$.

23. A. Mahboob, L. Dutcher. Dynamic approach to language proficiency - a model. In: Mahboob A, Barratt L (eds) Englishes in Multilingual Contexts: Language Variation and Education. London: Springer, 2015, pp.117-36.

24. H. Ahn.Teachers' attitudes towards Korean English in South Korea. World Englishes 2014, 33(2), pp.195-222.

25. N. N. H. Ton , H. H. Pham. Vietnamese teachers' and students' perceptions of global English. Language Education in Asia 2010, 1(1), pp.48-61.

26. G. Park. 'I am never afraid of being recognized as an NNES': one teacher's journey in claiming and embracing her non-native-speaker identity. TESOL Quarterly 2012, 46(1), pp.127-51. 
27. E. Llurda. Non-native Language Teachers: Perceptions, Challenges, and Contributions to the Profession. New York: Springer. 2005

28. H. Song. Deconstruction of cultural dominance in Korean EFL textbooks. Intercultural Education. 2013, 24(4), pp.382-90.

29. K. M. Yuen .The representation of foreign cultures in English textbooks. ELT Journal 2011, 65(4), pp.458-66.

30. Z. E. Pudyastuti, N. Atma. Englishes: Indonesian EFL Teachers' Perception.Parole Journal of Linguistics and Education. 2014, 4 (1), pp.76-82.

31. Yin \& K. Robert. Case study research, design and methods 2003 , 3(5). Thousand Oaks: Sage.

32. G. A. Kelly. The psychology of personal constructs.: A theory of personality. 1. New York: Norton. 1955.

33. F. Fransella, \& D. Bannister. A manual for repertory grid technique.. London: Academic press, Inc. 1977.

34. B. J. Terrill, \& A. Flitman. 'Using repertory grid analysis to gather qualitative data for information systems research' in Proceedings of The Thirteenth Australasian Conference on Information Systems (ACIS). Melbourne, Australia. 2002.

35. N. Beail, \& S. Beail. Evaluating dependency. In N. Beail (ed.) Repertory grid technique and personal constructs: applications in clinical and educational settings. London: Croom Helm. 1985.

36. J. T. Coshall. . Measurement of tourists' images: The repertory grid approach. Journal Travel Research.2000, 39, pp.85-89.

37. T. Palys. Purposive sampling.In L. M. Given (Ed.) The Sage Encyclopedia of Qualitative Research Methods. Sage: Los Angeles, 2008, 2, pp.697-8.

38. V. Braun, \& V. Clarke. Using thematic analysis in psychology.Qualitative Research in Psychology 2006, 3 pp.77-101.

39. U. Graneheim \& B. Lundman . Qualitative content analysis in nursing research: concepts, procedures and measures to achieve trustworthiness. Nurse Educ. Today. 2004, 24, pp.105-112.

40. A. Holliday. Native-speakerism.ELT Journal. 2006, 60(4), pp.385-87. 